\title{
Productive performance and quality of arugula (Eruca sativa) under different doses of cassava wastewater containing potassium source
}

\author{
Anderson Vitor Lins da Silva ${ }^{1}$, Aldair de Souza Medeiros ${ }^{1}$, Giordano Bruno Medeiros Gonzaga ${ }^{1}$, Ivomberg \\ Dourado Magalhães ${ }^{1,6}$, Renato Américo de Araújo Neto ${ }^{2}$, Rener Luciano de Souza Ferraz ${ }^{3,7 *}$, Sebastião de \\ Oliveira Maia Júnior ${ }^{4,7}$, Luan Danilo Ferreira de Andrade Melo ${ }^{1}$, Patrícia da Silva Costa ${ }^{4}$, Thiago Alves \\ Pimenta ${ }^{5}$, Joicy Lima Barbosa ${ }^{1}$, Mariana de Oliveira Pereira ${ }^{4}$
}

\author{
${ }^{1}$ Department of Plant Production, Federal University of Alagoas, Rio Largo, Brazil \\ ${ }^{2}$ Department of Engineer, "Mauricio de Nassau" University Center, Maceio, Brazil \\ ${ }^{3}$ Department of Agroecology and Agriculture, State University of Paraíba, Lagoa Seca, Paraíba, Brazil \\ ${ }^{4}$ Agricultural Engineering Academic Unit, Federal University of Campina Grande, Campina Grande, Paraíba, Brazil \\ ${ }^{5}$ Department of Plant Protection, Federal University of Alagoas, Rio Largo, Brazil \\ ${ }^{6}$ Fellow of CAPES Postdoctoral, PNPD, Brazil \\ ${ }^{7}$ Fellow of CNPq Postdoctoral, PDJ, Brazil
}

*Corresponding author: ferragroestat@gmail.com

Abstract

Cassava wastewater has high organic load and concentration of nutrients and can cause damage to the environment when discarded indiscriminately. However, the residue can help agricultural production. Therefore, this study aimed to determine the appropriate doses of cassava wastewater to enable the highest production and quality of arugula. The experiment was conducted in a greenhouse, in a completely randomized design, consisting of eight treatments composed of the following doses: $D_{1}=0, D_{2}=$ 6.5, $D_{3}=13, D_{4}=19.5, D_{5}=26, D_{6}=32.5, D_{7}=39$ and $D_{8}=45.5 \mathrm{~m}^{3} \mathrm{ha}^{-1}$ of cassava wastewater with four replicates each. We used the arugula cultivar "Cultivada", and samples of plant height, fresh matter, and shoot dry matter were performed at 15 and 30 days after emergence. The quality of arugula was evaluated through $\mathrm{pH}$, total soluble solids and titratable total acidity. Cassava wastewater had a significant effect on plant height, fresh matter and dry matter of above ground part, pH and total soluble solids of arugula. However, titratable total acidity was not affected by treatments. Our results show that cassava wastewater is a good alternative fertilizer for arugula cultivation but at proper doses up to $26 \mathrm{~m}^{3}$ ha ${ }^{-1}$ applied through the crop cycle to avoid the deleterious effect of some nutrients in excess, such as potassium.

Keywords: Brassicaceae; Manihot esculenta; biofertilizer; production quality.

Abbreviations: ATT_total titratable acidity; CECA_Agricultural Sciences Center; DAE_days after emergence; DMA_dry matter of the above ground part; Embrapa_Brazilian Agricultural Research Corporation; FMA_fresh matter of the above ground part; IBGE_ Brazilian Institute of Geography and Statistics; IPA_Pernambuco Agricultural Research Company; LAPA_Laboratory of Analysis of Agricultural Products; MAPA_Ministry of Agriculture, Livestock and Supply; PH_plant height; SST_total soluble solids; UFAL_Federal University of Alagoas.

\section{Introduction}

Arugula (Eruca sativa) is an herbaceous hardwood crop of the Brassicaceae family (Silva et al., 2009), has rapid vegetative growth, short cycle, and high yield per area (Oliveira et al., 2013). This plant needs mild temperatures, varying from 15 to 25 o C (Silva et al., 2009; Costa et al., 2011). The production period begins in the emergence of the seedlings and extends until the floral initiation, corresponding to its economically viable production (Jardina et al., 2017). Brazilian production of arugula in 2017 was 41,778 tons, and the state of São Paulo was the largest producer (18,548 tons), followed by Rio Grande do Sul (4,819 tons) and Paraná (3,276 tons) (IBGE, 2017). Production of the state of Alagoas was only 107 tons, that is, the 22nd producer of arugula in Brazil (IBGE, 2017).

The state of Alagoas presents favorable edaphoclimatic conditions for the cultivation of arugula, mainly in the region
"Zona da Mata", which has an annual average temperature of $25.4^{\circ} \mathrm{C}$ and an average rainfall of $1,800 \mathrm{~mm}_{\text {year }}{ }^{-1}$ (Magalhães et al., 2017). Therefore, the low production of arugula in Alagoas is probably related to the management conditions. Family farmers produce arugula and have low purchasing power and lack of access to more rational techniques of soil and water use. The proper fertilization in these systems can boost production. However, chemical fertilizers represent the main cost of production (Duarte et al., 2013), and the use of fertilizers without proper management contributes to environmental pollution (Araújo et al., 2017). Thus, the use of organic waste in agriculture seems an excellent alternative to mitigate these problems (Moura et al., 2018). 
Cassava wastewater is one of the main residues obtained during the production of starch or flour from cassava (Manihot esculenta Crantz) (O-Thong et al., 2011; Dantas et al., 2017), contains high levels of carbohydrates, sugars, lipids, cyanuric acid, starches, and others substances (Dantas et al., 2015; Andreani et al., 2019). The residue is also rich in macro and micronutrients, essential for the growth and development of plants (Avancini et al., 2007; Moura et al., 2018). However, cassava wastewater should be used carefully since it is harmful to the environment due to the high organic load and linamarina, which is a cyanogenic glycoside of high toxicity (Shang et al., 2018). However, the proper use of the residue does not lead to environmental contamination and enables agricultural production (Bezerra et al., 2019). Thus, its use might be a source of organic fertilizer with high potential to replace synthetic fertilizers.

The use of cassava wastewater as a source of nutrients has promoted promising results during the cultivation of several crops. For example, Santos et al. (2010) found an increase in the number of leaves and leaf area index of lettuce using wastewater cassava as fertilizer, and Duarte et al. (2012) found higher plant height, leaf area, and fresh and dry matter production. Barreto et al. (2013) observed an increase in the production of fresh matter, and nitrogen and potassium contents of the above ground part of maize plants fertilized with cassava wastewater, and Dantas et al. (2015) reported the increases in plant height, number of leaves, fresh matter and leaf dry matter in sunflower cultivation.

To reduce the damages to the environment by the incorrect disposal of cassava wastewater, and to supply the nutritional needs of crops reusing cassava wastewater decreasing the production costs with the use of chemical fertilizers, this study aimed to determine the adequate doses of cassava wastewater to enable the highest production and quality of arugula.

\section{Results and Discussion}

\section{Plant height}

Cassava wastewater had a significant effect $(\mathrm{P}<.001$ and $\mathrm{P}=$ $.05)$ on plant height at 15 (15 DAE) and 30 days after the emergence ( $30 \mathrm{DAE}$ ). Figure 1 shows that the mean values of plant height under increasing doses of cassava wastewater showed a quadratic adjustment, and the plants that received this residue presented higher plant height, which ranged from 0.1 and $30.6 \%$ when compared to control treatment $(0$ $\mathrm{m}^{3} \mathrm{ha}^{-1}$ ). This behavior was probably due to the higher nutrient supply to the plants submitted to the treatments containing cassava wastewater (Avancini et al., 2007; Dantas et al., 2015; Araújo et al., 2017).

The highest values of mean plant heights were found in the plants under the doses 22.8 and $26.5 \mathrm{~m}^{3} \mathrm{ha}^{-1}$, reaching 14.2 and $18.9 \mathrm{~cm}$ at 15 and $30 \mathrm{DAE}$, respectively, showing reductions in plant height at higher doses. These results show that plants grown under optimum doses (22.8 and $26.5 \mathrm{~m}^{3} \mathrm{ha}^{-1}$ ) had 25.8 and $1 \%$ higher values at $15 \mathrm{DAE}$, while at 30 DAE the increases were 22.2 and $2.3 \%$, in relation to the plants that did not receive doses of cassava wastewater and those that received the recommended dose $\left(26.0 \mathrm{~m}^{3}\right.$ ha $\left.{ }^{1}\right)$, respectively. The decreasing in plant height at doses above the inflection point may be related to the deleterious effect of some nutrient, such as potassium, since it is the element of greatest occurrence in cassava wastewater, and when in excess impairs the absorption of other essential nutrients by the plant (Duarte et al., 2012; Andreani et al., 2019).
The highest plant height $(18.9 \mathrm{~cm})$ was found at the dose $26.5 \mathrm{~m}^{3} \mathrm{ha}^{-1} 30 \mathrm{DAE}$, which was higher than the value observed by Carvalho et al. (2012) $(16.3 \mathrm{~cm})$ in arugula crop under conventional fertilization, and close to the $21 \mathrm{~cm}$ found by Linhares et al. (2011) for the cultivation of arugula under organic fertilization. Duarte et al. (2012) evaluated different doses of cassava wastewater and found a higher height $(18.7 \mathrm{~cm})$ of lettuce at the treatment of $45 \mathrm{~m}^{3} \mathrm{ha}^{-1}$, which was $31 \%$ higher than that observed in plants that did not receive this organic residue. Several authors have already noted the fertilizer effect of cassava wastewater in different crops (Santos et al., 2010; Duarte et al., 2012; Dantas et al., 2015, 2017; Bezerra et al., 2019).

\section{Accumulation of fresh matter and dry matter of the above ground part}

Statistical analysis revealed significant effects $(P<0.001)$ of cassava wastewater on fresh and dry matter of the above ground part of arugula. The regression equations adjusted to the experimental data of these variables presented quadratic behavior (Figs 2A and 2B). Our data show that the fresh matter increased with cassava wastewater doses up to the estimated limit of $22.9 \mathrm{~m}^{3} \mathrm{ha}^{-1}$, a gain of 28.6 and $3.5 \%$ when compared to the treatments in the absence of the residue and the dose of $26 \mathrm{~m}^{3} \mathrm{ha}^{-1}$ (100\% of the potassium recommendation). There was an increase of dry matter up to the estimated dose of $20.3 \mathrm{~m}^{3} \mathrm{ha}^{-1}$ of cassava wastewater, reducing dry matter at higher doses. We verified gains in the dry matter in the order of 22.9 and $7.5 \%$ concerning the control $\left(0 \mathrm{~m}^{3} \mathrm{ha}^{-1}\right)$ and the recommended dose $\left(26 \mathrm{~m}^{3} \mathrm{ha}^{-1}\right)$, respectively.

The influence of cassava wastewater doses on the biomass production of arugula was expected, since the height of the plant was significantly affected by the treatments (Fig. 1), which would consequently influence the accumulation of fresh and dry matter. Cassava wastewater is rich in macro and micronutrients (Barreto et al., 2014; Shang et al., 2018), which are essential for the growth and development of crops. Our results agreed with Duarte et al. (2012) when they observed an increase in the fresh and dry above ground mass of lettuce as cassava wastewater doses increased, reaching $45 \mathrm{~m}^{3} \mathrm{ha}^{-1}$ and declining after that level. Also, for lettuce, Santos et al. (2010) observed similar behavior of biomass production increased up to the limit of $396 \mathrm{~mL}$ per vessel, decreasing after this value.

The decreases in fresh and dry matter observed at the doses above the maximum response point may be related to the excess of potassium in the soil solution, promoted by the higher doses of the residue, and when this element is in excess, it compromises the absorption of the other essential elements, especially calcium, iron, magnesium, manganese and zinc (Avancini et al., 2007; Dantas et al., 2015). When that nutrient absorption is compromised, there is a reduction in the plant biochemical processes since they are associated with several enzymatic functions in plants, such as the synthesis of chlorophyll (Taiz et al., 2017).

Therefore, our results confirm the fertilizer benefits of cassava wastewater due to the essential nutrients for plant development, such as potassium, magnesium, phosphorus, and calcium. According to Barreto et al. (2013), cassava wastewater has a high potential for reuse in agriculture in the form of fertilizer, but it should be used rationally since it can cause environmental degradation when in excess (Table 1). 
Table 1. Summary of Analysis of Variance on the variables plant height at 15 (PH 15) and 30 (AP 30) days after emergence, above ground fresh matter (FMA), above ground dry mass (DMA), pH, soluble solids (TSS) and total titratable acidity (TTA) of the arugula as a function of cassava wastewater doses.

\begin{tabular}{|c|c|c|c|c|c|c|c|}
\hline \multirow{2}{*}{ Source of variation } & \multicolumn{7}{|c|}{ F-test } \\
\hline & $\mathrm{PH}$ (15 DAE) & $\mathrm{PH}$ (30 DAE) & FMA & DMA & $\mathrm{pH}$ & SST & TTA \\
\hline Doses of Cassava & $4.65 * *$ & $2.44 *$ & $38.30 * *$ & $11.51^{* *}$ & $21.44 * *$ & $32.36 * *$ & 2.30 \\
\hline Linear regression & 0.00 & 3.85 & 14.36 & 6.59 & $142.96 * *$ & 9.46 & 1.61 \\
\hline Quadratic regression & $28.02 * *$ & $10.38^{*}$ & $187.05^{* *}$ & $42.54 * *$ & 0.18 & $175.15^{* *}$ & 4.29 \\
\hline C.V. (\%) & 12.71 & 11.13 & 4.39 & 7.34 & 3.12 & 8.28 & 4.75 \\
\hline
\end{tabular}

$*^{* *}, *: P<.001$ e $P=.05$, respectively, by the $\mathrm{F}$ test; C.V. $(\%)$ - coefficient of variation.

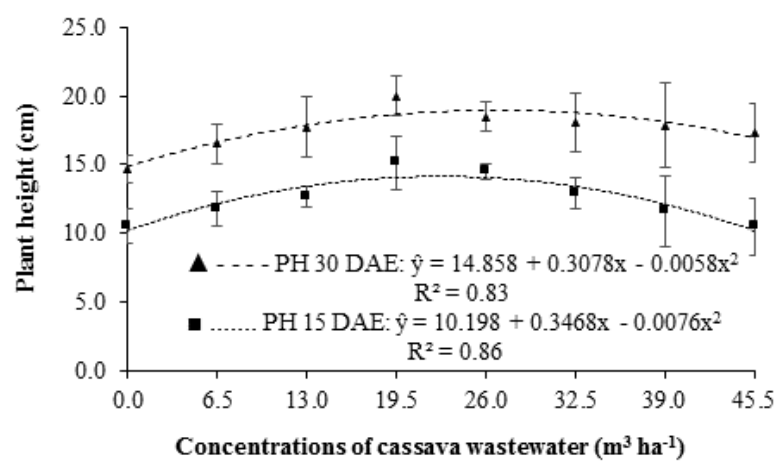

Fig 1. Height of arugula plants as a function of increasing doses of cassava wastewater at 15 and 30 days after emergence.

Table 2. Chemical analysis of the soil used in the experiment.

\begin{tabular}{|c|c|c|c|c|c|c|c|c|c|c|c|c|c|c|}
\hline & $\mathrm{pH}$ & $\mathrm{Na}$ & $\mathrm{P}$ & $\mathrm{K}$ & $\mathrm{Ca}$ & $\mathrm{Mg}$ & $\mathrm{Al}$ & $\mathrm{H}+\mathrm{Al}$ & $\mathrm{Cu}$ & $\mathrm{Zn}$ & $\mathrm{Mn}$ & SB & CTC & V \\
\hline & \multicolumn{4}{|c|}{$\mathrm{mg} \mathrm{dm}^{-3}$} & \multicolumn{3}{|c|}{$\mathrm{mmolc} \mathrm{dm}^{-3}$} & \multicolumn{4}{|c|}{$\mathrm{mg} \mathrm{dm}{ }^{-3}$} & \multicolumn{2}{|c|}{ mmolc dm ${ }^{-3}$} & $\%$ \\
\hline 5.2 & & 16 & 5 & 57 & 0.9 & 0.8 & 0.68 & 3.7 & 0.6 & 0.42 & 0.91 & 1.92 & 5.62 & 34.1 \\
\hline
\end{tabular}

pH - saturation extract pH; Na - Sodium; P - Phosphorus; K - Potassium; Ca - Calcium; Mg - Magnesium; Al - Aluminum; H + Al - Hydrogen + Aluminum; Cu - Copper; Zn - Zinc; Mn-Manganese; SB Sum of bases; CTC - Cation exchange capacity; $\mathrm{V}$ - base saturation.
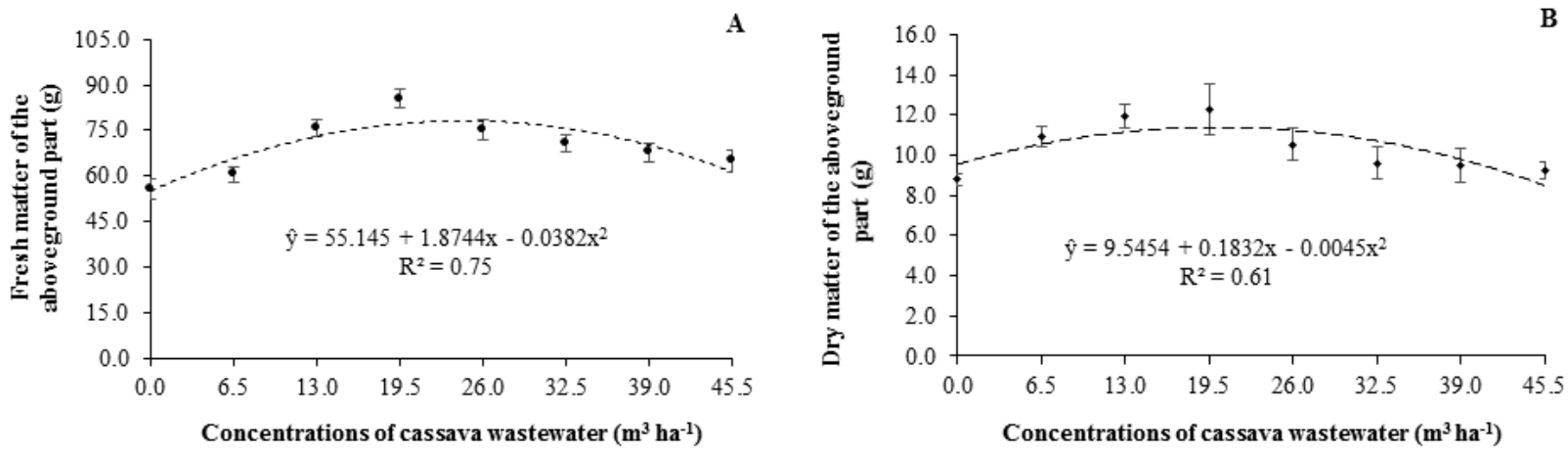

Fig 2. Fresh (A) and dry matter (B) of the above ground part of the arugula submitted to different doses of cassava wastewater.

Table 3. Chemical analysis of cassava wastewater used in the experiment.

\begin{tabular}{lllllllllll}
\hline $\mathrm{pH}$ & $\mathrm{Na}$ & $\mathrm{P}$ & $\mathrm{K}$ & $\mathrm{Ca}$ & $\mathrm{Mg}$ & $\mathrm{Cu}$ & $\mathrm{Zn}$ & $\mathrm{Mn}$ & Condutividade & $\mathrm{C} / \mathrm{N}$ \\
\hline \multicolumn{7}{c}{$\mathrm{mg} \mathrm{dm}^{-3}$} & & \multicolumn{2}{l}{$\mathrm{mmolc} \mathrm{dm}^{-3}$} & \multicolumn{7}{l}{$\mathrm{mg} \mathrm{dm}^{-3}$} & & $\mathrm{~ms} \mathrm{~cm}^{-1}$ & \\
3.61 & 1850 & 22 & 4000 & 24 & 50 & 2.52 & 6.12 & 0.54 & 13.34 & $8: 1$
\end{tabular}

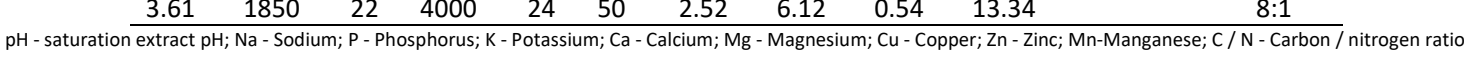
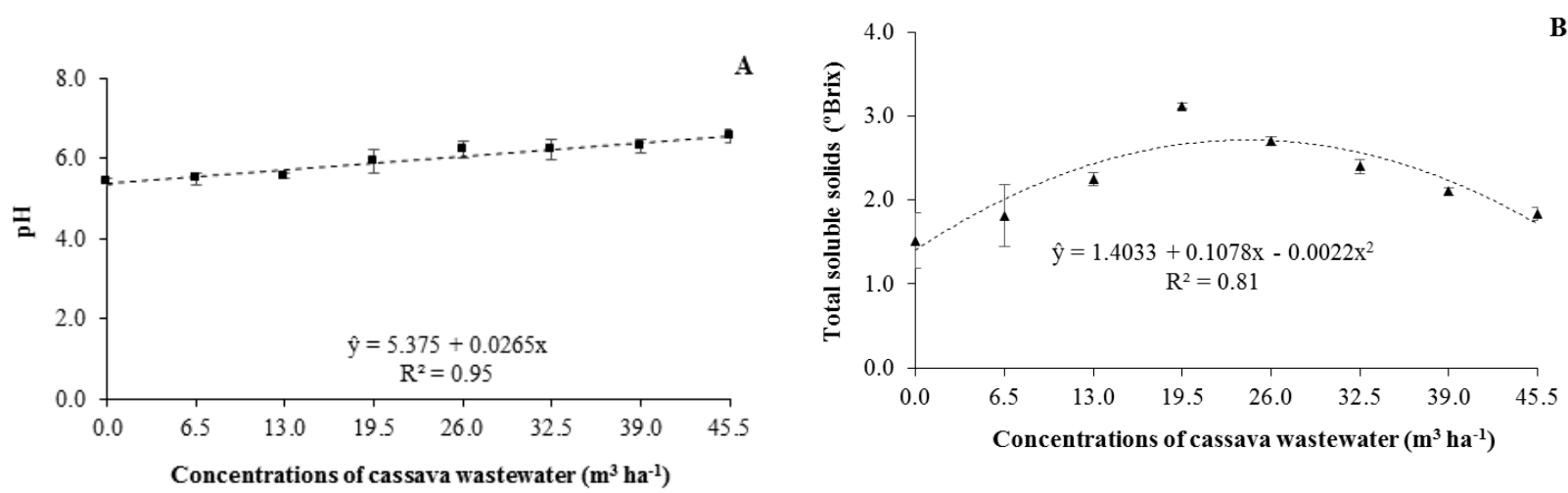

Fig 3. $\mathrm{pH}$ values $(\mathrm{A})$ and total soluble solids $(\mathrm{B})$ in arugula plants submitted to increasing doses of cassava wastewater. 


\section{Quality characteristics of arugula after the harvest}

Our data show a significant influence $(P<.001)$ of cassava wastewater doses applied on the values of $\mathrm{pH}$ and total soluble solids (-Brix), with coefficients of determination of 0.95 and 0.81 , respectively (Figs $3 \mathrm{~A}$ and $3 \mathrm{~B}$ ). However, titratable total acidity was not affected by treatments. Data of $\mathrm{pH}$ were better adjusted to the linear regression model, with an increase of $0.49 \%$ per unit increase of cassava wastewater applied. This previous results show that there was a $22.3 \%$ increase in the $\mathrm{pH}$ of the plants at the maximum dose $\left(45.5 \mathrm{~m}^{3} \mathrm{ha}^{-1}\right)$ compared to plants that did not receive the cassava residue. The increase in $\mathrm{pH}$ may have occurred due to the increase of the organic acids present in the plant, possibly related to the greater nutrient supply by the cassava wastewater, and consequently increasing in ions absorption by the plant (Santos et al., 2010; O-Thong et al., 2011; Moura et al., 2018).

According to the regression analysis (Fig. 3B), the averages of total soluble solids (oBrix) presented a quadratic adjustment with cassava wastewater doses. The estimated optimal dose occurred at $24.5 \mathrm{~m}^{3}$ ha ${ }^{-1}$ promoting the highest value of TSS 2.84 ( ${ }^{\circ} \mathrm{Brix}$ ), with reductions at doses above this level. We observed an increase of TSS of 46.8 and $4.9 \%$ concerning the treatments without organic fertilizer and with the recommended dose $\left(26 \mathrm{~m}^{3} \mathrm{ha}^{-1}\right)$, respectively. Increases in total soluble solids up to the maximum response dose of cassava wastewater probably occurred due to the improvement of the physical, chemical and biological properties of the soil caused by this organic residue. In organic cultivations, soil fertility increases by the chelation effect of the organic molecule complex present in the organic fertilizer (in this case, cassava wastewater), resulting in greater solubilization of the nutrients and mobilization to the plant systems, consequently, the plants become nutritionally balanced (Araújo et al., 2017; Dantas et al., 2017; Bezerra et al., 2019).

The effects of reductions from the optimal dose of cassava wastewater observed in the present study should be related to the increase of the microbial population, due to the greater availability of the organic residue, causing greater consumption of available nutrients and consequently reduction their availability for plants (Barreto et al., 2013; Araújo et al., 2017; Shang et al., 2018). And, the decrease in total soluble solids may have occurred in response to the toxic effect on plants, promoted by excess nutrients at higher doses of cassava wastewater (Avancini et al., 2007; Santos et al., 2010; Dantas et al., 2015; Andreani et al., 2019).

Our results are close to the values found by Campos et al. (2013) when they observed $\mathrm{pH}$ of 4.8 and 4.6, total soluble solids of 3.72 and $3.26^{\circ}$ Brix for arugula cultivations under organic and mineral fertilization, respectively. Nunes et al. (2013) found a pH of 5.76 and TSS of $3.32^{\circ}$ Brix for arugula cultivated in organic systems. Jardina et al. (2017) found significant effects of $\mathrm{pH}$ values between arugula varieties in a semi-hydroponic system, with data varying from 5.66 to 5.81 , but it was not observed a significant effect on total soluble solids, which varied from 3.45 to $3.54^{\circ}$ Brix. Using mineral fertilization, Vasconcelos et al. (2011) found $\mathrm{pH}$ values and total soluble solids of 5.68 and $4.92^{\circ} \mathrm{Brix}$ for arugula "Cultivada", and TSS was $42.3 \%$ higher than that found in the present study.
Materials and Methods

\section{Plant materials}

The experiment was conducted from May to August 2018, in a protected environment at the Agricultural Sciences Center (CECA) belonging to the Federal University of Alagoas (UFAL), in Rio Largo, state of Alagoas, Brazil $\left(09^{\circ} 28^{\prime} 02^{\prime \prime} \mathrm{S}\right.$, $35^{\circ} 49^{\prime} 43^{\prime \prime} \mathrm{W}$ and altitude of $127 \mathrm{~m}$ ). The climate of Rio Largo - AL, according to the classification of Köppen, is tropical sub-humid, with two well defined seasons, dry and rainy periods, with an average annual temperature of 25.4 으 and an average rainfall of $1,800 \mathrm{~mm}^{-1}$ year $^{-1}$ (Magalhães et al., 2017).

\section{Treatments and experimental design}

The treatments were determined taking into account the concentration of potassium (K) in cassava wastewater and soil, as well as the potassium requirement for arugula crop, which is $26 \mathrm{~m}^{3}$ ha ${ }^{-1}$ (IPA, 2008). The treatments consisted of eight doses of cassava wastewater $D_{1}=0, D_{2}=6.5, D_{3}=13$, $D_{4}=19.5, D_{5}=26, D_{6}=32.5, D_{7}=39$, and $D_{8}=45.5 \mathrm{~m}^{3} \mathrm{ha}^{-1}$, corresponding respectively to $0 ; 25 ; 50 ; 75 ; 100 ; 125 ; 150$ and $175 \%$ of $\mathrm{K}$ recommendation for arugula crop (IPA, 2008). Each treatment was replicated four times totalizing 32 experimental units. The experimental design was completely randomized. The treatments were added to the pots where the plants were cultivated using a test tube nine days before transplanting seedlings.

\section{Conduction of study}

We used a Coarse Yellow Latosol soil, collected at $0-40 \mathrm{~cm}$ depth. To carry out the chemical and physical characterization of the soil, ten samples were performed for the chemical and physical characterization of the soil, using an auger, air dried, smashed and sieved in a $2 \mathrm{~mm}$ mesh, then a composite sample was formed. The physical and chemical characterization of the soil (Table 2) was performed at the Laboratory of Soil and Plant Nutrition, at UFAL, according to the methodology proposed by Embrapa (1997).

Plant cultivation was carried out in pots of $9 \mathrm{~L}$ filled with $2 \mathrm{~kg}$ of gravel (number zero), covering the base of the pot, and a layer of soil above. The soil was placed in field capacity, using the capillary saturation method and free drainage. After sowing, daily irrigations were performed. The water volume applied obeyed the water requirement of the plant, determined by the water balance, the volume applied minus the volume drained in the previous irrigation.

The variety used in the experiment was "Cultivada" arugula (Eruca sativa Miller), which is the main variety in Brazil and has high adaptability to the conditions of the Northeast region. Arugula was sown in double-row vessels with spacing of $5 \mathrm{~cm}$ between plants. All treatments received a covering of limestone to raise the saturation by bases (V\%) to $80 \%$, $400 \mathrm{~kg}$ of $\mathrm{P}_{2} \mathrm{O}_{5} \mathrm{ha}^{-1}$ (super triple) and $40 \mathrm{~kg}$ of $\mathrm{N} \mathrm{ha}^{-1}$ (Ammonium Sulphate) at 10 and 15 days after germination. Cassava wastewater was provided by a flour house located in the area of São Sebastião, AL. After application of cassava wastewater, all the pots were incubated for 9 days. The physical and chemical characterization of cassava wastewater (Table 3) was performed at the Laboratory of Analysis of Agricultural Products (LAPA) of UFAL. The 
determination of the physical and chemical parameters was performed according to the methodology described by MAPA (1988).

\section{Variables analyzed}

\section{Plant height $(\mathrm{PH})$}

Growth evaluations were performed by plant height in $\mathrm{cm}$, at 15 and 30 days after emergence (DAE), measuring from the soil level to the leaf end.

\section{Accumulation of fresh matter and dry matter of the above ground part}

At 30 DAE the plants were harvested and the accumulation of fresh matter of the above ground part (FMA) in $g$ was obtained from the plants collected from each vase, using a balance with digital precision. Afterwards, the material was placed in an air circulating oven for drying at 65ㅇ until obtaining a constant mass, obtaining the dry matter of the above ground part (DMA) in g.

\section{Quality characteristics of arugula after the harvest}

To evaluate the quality characteristics of arugula after the harvest, we measured the total soluble solids (SST) - by the refractive index in portable refractometer, total titratable acidity (ATT) by neutralization reaction with $\mathrm{NaOH} 0.1 \mathrm{~N}$ and phenolphthalein as indicator solution; and $\mathrm{pH}$ by direct reading the juice through previously calibrated $\mathrm{pH}$ meter.

\section{Statistical analysis}

To test the difference among treatments, we used the analysis of variance by the $F$ test $(P \leq 0.05)$, and in the case of significance, a polynomial regression analysis was performed to unfold the effects of cassava wastewater doses. We used the statistical software SISVAR (Ferreira, 2014).

\section{Conclusion}

Our results show that the use of cassava wastewater as an alternative to chemical fertilization for arugula cultivation increase the plant height, fresh and dry above ground matter, $\mathrm{pH}$, and total soluble solids contents.

The data also show that cassava wastewater is a good alternative fertilizer for arugula cultivation but at proper doses up to $26 \mathrm{~m}^{3} \mathrm{ha}^{-1}$ applied through the crop cycle to avoid the deleterious effect of some nutrients in excess, such as potassium.

\section{References}

Andreani CL, Tonello TU, Mari AG, Leite LCC, Campaña HD, Lopes DD, Rodrigues JAD, Gomes SD (2019) Impact of operational conditions on development of the hydrogenproducing microbial consortium in an AnSBBR from cassava wastewater rich in lactic acid. Int J Hydrogen Energy. 44:1474-1482.

Araújo NC, Lima VLA, Sena LF, Ramos JG, Borges VE, Bandeira FA (2017) Organic production of lettuce in fertilized substrate with yellow and cassava wastewater water. Rev Bras Agric Irrig. 11(8):2111-2119.
Araújo NC, Oliveira SJC, Ferreira TC, Lima VLA, Queiroz AJP, Araújo FAC (2015) Growth and yield of corn fertilized with manipueira as an alternative source of nutrients. Rev Tecnol Cienc Agropec. 9(2):31-35.

Avancini SRP, Faccin GL, Vieira MA, Rovaris AA, Podestá R, Tramonte R, Souza NMA, Amante ER (2007) Cassava starch fermentation wastewater: Characterization and preliminary toxicological studies. Food Chem Toxicol. 45:2273-2278.

Barreto MTL, Magalhães AG, Rolim MM, Pedrosa EMR, Duarte AS, Tavares EU (2014) Growth and accumulation of macronutrients in maize plants biofertilized with cassava wastewater. Rev Bras Eng Agr Amb. 18(5):487-494.

Barreto MTL, Rolim MM, Pedrosa EMR, Magalhães AG, Tavares EU, Duarte AS (2013) Chemical attributes of two soils under cassava wastewater application. Rev Bras Ciênc Agrár. 8(4):528-534.

Bezerra MGS, Silva GGC, Difante GS, Emerenciano Neto JV, Oliveira EMM, Morais ÉG (2019) Chemical attributes of soil under cassava wastewater application in Marandu grass cultivation. Rev Bras Eng Agr Amb. 23(8):579-585.

Campos B, Oliveira VS, Oshiro AM (2013) Assessment of chemical rocket from different sources. Interbio. 7(1):5460.

Carvalho KS, Bonfim-Silva EM, Silveira MHD, Cabral CEA, Leite N (2012) Arugula submitted fertilization nitrogen via fertigation. Encicl Biosf. 8(15):1545-1553.

Costa CMF, Seabra Júnior S, Arruda GR, Souza SBS (2011) Performance of cultivars of arugula under shade screens and open field. Semina: Ciênc Agrár. 32(1):93-102.

Dantas MSM, Rolim MM, Duarte AS, Lima LE, Silva MM (2017) Production and morphological components of sunflower on soil fertilized with cassava wastewater. Rev Ceres. 64(1):077-082.

Dantas MSM, Rolim MM, Duarte AS, Pedrosa EMR, Tabosa JN, Dantas DC (2015) Growth of sunflower fertilized with liquid waste from processing of cassava. Rev Bras Eng Agr Amb. 19(4):350-357.

Duarte AS, Rolim MM, Silva ÊFF, Pedrosa EMR, Albuquerque FS, Magalhães AG (2013) Changes in physical and chemical properties of soil after application of cassava wastewater. Rev Bras Eng Agr Amb. 17(9):938-946.

Duarte AS, Silva ÊFF, Rolim MM, Ferreira RFAL, Malheiros SMM, Albuquerque FS (2012) Use of different doses of cassava wastewater in lettuce crop in substitution of mineral fertilizer. Rev Bras Eng Agr Amb. 16(3):262-267.

Embrapa - Empresa Brasileira de Pesquisa Agropecuária (1997) Manual of soil analysis methods. Centro Nacional de Pesquisa de Solos, Rio de Janeiro, Brazil. p 212.

Ferreira DF (2014) SISVAR: A guide for its bootstrap procedures in multiple comparisons. Ciênc Agrotec. 38(2):109-112.

IBGE - Instituto Brasileiro de Geografia e Estatística (2017) Horticulture Products - Arugula. Municipal Livestock Research. Available at: https://sidra.ibge.gov.br/Tabela/6619\#resultado. [Accessed May. 25, 2019].

IPA - Empresa Pernambucana de Pesquisa Agropecuária (2008) Fertilizer recommendations for the state of Pernambuco. 2nd edn. Recife, Brazil. p 198.

Jardina LL, Cordeiro CAM, Silva MCC, Sanches AG, Araújo Júnior PV (2017) Productive performance and quality of arugula cultivars in semi-hydroponic system. Rev Agric Neotrop. 4(1):78-82. 
Linhares PCF, Maracajá PB, Bezerra AKH, Pereira MFS, Paz, AES (2011) Yield of rocket cultivars under different amounts and Merremia aegyptia L. Rev Verde Agroec Desenv Sustent. 6(2):7-12.

Magalhães ID, Lyra GB, Souza JL, Teodoro I, Cavalcante CA, Ferreira Junior RA, Souza RC (2017) Physiology and grain yield of common beans under evapotranspirated water reposition levels. Irrig Drain Syst Eng. 6(1):1-8.

MAPA - Ministério da Agricultura, Pecuária e Abastecimento (1988) Laboratório Nacional de Referência Vegetal. Análise de corretivos, fertilizantes e inoculantes: métodos oficiais. Brasília, Brazil. p 104.

Moura AS, Medeiros EV, Oliveira JES, Franca RF, Lira AD, Martins Filho AP, Badji CA (2018) Does cassava wastewater with a short incubation time affect soil organic carbon, microbial community and enzymatic activities?. Catena. 163:354-360.

Nunes CJS, Souza ML, Ferreira RLF (2013) Quality and postharvest of organic rocket stored under refrigeration. Encicl Biosf. 9(17):2231-2240.

Oliveira FA, Souza Neta ML, Silva RT, Souza AAT, Oliveira MKT, Medeiros JF (2013) Performance of rocket cultivars under different nutritive solutions with salinity different. Rev Agro@mb On-line. 7(2):170-178.

O-Thong S, Hniman A, Prasertsan P, Imai T (2011) Biohydrogen production from cassava starch processing wastewater by thermophilic mixed cultures. Int J Hydrogen Energy. 36:3409-3416.
Santos MHV, Araújo AC, Santos DMR, Lima NS, Lima CLC, Santiago AD (2010) Use of cassava industry wastewater as a potassiun source on lettuce crop (Lactuca sativa L.) in greenhouse conditions. Acta Sci Agron. 32(4):729-733.

Shang Q, Tang H, Wang Y, Yu K, Wang L, Zhang R, Wang S, Xue R, Wei C (2018) Application of enzyme-hydrolyzed cassava dregs as a carbon source in aquaculture. Sci Total Environ. 615:681-690.

Silva LJB, Cavalcante ASS, Araújo Neto SE (2009) Production of rocket (Eruca sativa) seedlings with substrates composed of organic waste. Ciênc Agrotec. 33(5):13011306.

Taiz L, Zeiger E, Møller IM, Murphy A (2017) Fisiologia e desenvolvimento vegetal. 6. ed. Porto Alegre: Artmed, Brazil. p 858.

Vasconcelos RL, Freitas MPN, Brunini MA (2011) Physicochemical characteristics of arugula cv. "Cultivada" produced in the conventional system and baby leaf. Nucleus. 8(2):7-14. 